\title{
Colonización espiritual del campo, ayer y hoy: Romería de la Virgen de la Rogativa (Murcia, 1990)
}

\section{POBLAMIENTO, COLONIZACIÓN Y RELIGIOSIDAD}

La Encomienda santiaguista de Moratalla, como sus vecinas de Caravaca, Socovos, Yeste, Segura de la Sierra..., en el noroeste del Reino de Murcia, una vez conquistada Huéscar de manera definitiva en 1488, pasó a ser una vasta zona casi deshabitada que podía ser repoblada en sus fértiles cañadas y campos de pastizales ${ }^{1}$. Hasta entonces, desde que fue reconquistada en el siglo XIII por las tropas castellanas, sus amplios espacios habían permanecido casi deshabitados, en contraste con lo sucedido en la etapa anterior musulmana a partir del siglo $\mathrm{x}$ en que estuvieron poblados por dispersos asentamientos bereberes de origen clánico, desde los que se cultivaron y explotaron las tierras, en grupos de una o dos docenas de familias de un mismo tronco agnaticio, que se regulaban por su dependencia jurisdiccional del Hisn de Muratalla, y de los que sólo nos han llegado vestigios toponímicos como Benizar, Priego, Zacatín, Benamos, Alazor, Inazares, etc. ${ }^{2}$. Durante la etapa cristiana -iniciada con su reconquista e integración en Castilla en 1241 y repoblada en 1280 con la presencia, según nos refiere la tradición, de trece familias, por su condición de tierra fronteriza con la de los moros granadinos, y por tanto siempre en peligro de sufrir sus periódicas incursiones devastadoras ${ }^{3}$ - sus habitantes permanecieron domi-

1 En Moratalla, como por lo general en todo el noroeste murciano, y las áreas próximas de Albacete y Granada, desde la Edad Media, viene siendo tradicional utilizar las denominaciones de cañadas para las planicies extensas de los terrenos bajos cultivables, y campos para las tierras altas de los valles. Después quedaban los terrenos montuosos que, según decía Robles CORBALÁN: «comprehenden muchas sierras y vegas, donde ay muchos pinares, enzinares, murtas, esparto, romerales, grandes pastos para los ganados que son muchos los de esta tierra, porque ay gran copia de yeguas y bacas, cabras y ouejas» (Historia del mysterioso aparecimiento de la Santissima Cruz de Carabaca e inumerables milagros $q$ Dios ha obrado y obra por su devoción, Madrid, 1619, fol. 2 b).

2 Miguel Rodríguez Llopis, Señorios y Feudalismo en el Reino de Murcia. Los dominios de la Orden de Santiago entre 1440 y 1515 (Murcia, 1984), pp. 49 y ss.

${ }^{3}$ Sobre estas incursiones véase Abelardo MERINo ÁlvareZ, Geografía histórica de la provincia de Murcia (Madrid, 1915), pp. 84 y ss. 
ciliados dentro del recinto amurallado, al tiempo que se verificaba, de manera progresiva, la desaparición de las aldeas y grandes caseríos existentes poblados por mudéjares que, de manera paralela, fueron desapareciendo bien por huir hacia el reino nazarita, bien por ir integrándose dentro de la comunidad cristiana de la villa.

El modelo de poblamiento cristiano, que supuso una ruptura completa con el musulmán, permaneció inalterable durante siglos como consecuencia de las circunstancias que impusieron las relaciones con los granadinos, casi siempre belicosas, sobre todo en los siglos XIV y XV, que a su vez repercutieron en el desarrollo demográfico que se sostuvo dentro de unos márgenes mínimos: los campos continuaron dedicados en su mayor parte a proporcionar algo de caza y a pastos para la reducida cabaña que podía tornar al refugio de la villa al caer la tarde, mientras que solamente fueron cultivados los terrenos aledaños de la muralla repartidos en huertas. Enormes extensiones del término de Moratalla, como de las Encomiendas vecinas, permanecieron destinadas a pastizales de uso comunal que fueron mediatizadas en la práctica foral, conforme se asentó el poder de la Orden de Santiago, haciendo que dicho uso fuese regulado por el concejo o bien pasase a depender por propiedad de ella de la aristocracia militar.

Pero a partir de 1490 , y sobre todo de 1492 con la conquista por los Reyes Católicos del último reducto nazarita, la ciudad de Granada, por la presencia de nuevos pobladores, comenzó a desarrollarse una expansión generalizada de las roturaciones en terrenos cada vez más alejados de la villa, al levantarse caseríos en los que podía desarrollarse la vida de manera autosuficiente: las tierras de Zacatín, Cañada de la Cruz, Benizar, Otos, comenzaron a ser repartidas entre familias de colonos para que practicasen en ellas la agricultura de cereales junto a una ganadería de tipo lanar preferentemente y de carga ${ }^{4}$.

El hecho de vivir la población de Moratalla dentro de la línea de muralla que la amparaba, a su vez, impuso que ésta participase y compartiese una larga serie de bienes y modos de vida tanto en el orden material como en el político, por más que se hiciese bajo el riguroso control y los condicionamientos sociales impuestos por la Orden de Santiago sobre lo regulado en el Fuero de Cuenca, su carta otorgada de repoblación, en la que se reservó expresamente, junto a otras puntualizaciones, el gobierno de la villa a los hidalgos que la habían repoblado en el siglo XviII, perviviendo dicha situación hasta que, muy avanzado el siglo $\mathrm{XV}$, se trató de reformar al

4 La población de Moratalla pasó a tener 250 vecinos en 1498, a 300 en 1507, a 450 en 1527 ... Ver J. I. GuTIÉRREZ NiETo, «Evolución demográfica del Segura en el siglo XVI», Hispania, 111 (1969), pp. 25 y ss. 
manifestarse abiertamente una pugna entre éstos y los caballeros cuantiosos, representantes de una nueva capa social emergente. Bajo la aristocracia, como cuerpo militar, y la reducida presencia de hombres de iglesia, quedó la masa popular siempre excluida de toda decisión política por mínima que fuera. $\mathrm{Y}$ junto al poder manifestado en el uso de monopolios de molinos, hornos, y del gobierno político, la Orden de Santiago ejerció una censura cerrada en lo tocante a la religión ya que absolutamente todo debía pasar por los cauces que imponía la única parroquia existente en la villa, la iglesia de Santa Marías y, por lo tanto, el lugar sagrado idóneo para que la población cumpliese con los preceptos religiosos, a la vez que establecía contacto directo con la divinidad y lo sobrenatural por medio de la oración y adoración de sus imágenes, salvo en la excepción observada para el comendador (de la familia Fajardo hasta la primera mitad del siglo XVI) que tenía el privilegio de poseer una capilla privada en el castillo dedicada a Santa María Magdalena.

La consolidación de la paz en la Encomienda de Moratalla vino a significar una ruptura en las más diversas manifestaciones de la vida comunitaria, respecto a las observadas en la etapa anterior que se vio multiplicada al obrar también sobre ella la presencia de una población foránea ${ }^{6}$. Ésta, sin duda, aportó nuevos planteamientos a la colonización agraria de la comarca $y$, a la vez, nuevas ideas espirituales y religiosas que no tardaron en aflorar al obligar a que se ampliase el lugar sagrado, y por tanto de culto, fuera de la parroquia, por medio de manifestaciones muy peculiares, del mismo modo que venían obrándose en otros muchos lugares de España, y que a su vez eran remedo de otras que se habían dado anteriormente en lugares de la Europa mediterránea $?$.

5 Cristina GUtIERREZ-CorTINES CORRAL, Renacimiento y arquitecturaa religiosa en la antigua diócesis de Cartagena. (Reino de Murcia. Gobernación de Oribuela y Sierra del Segura) (Murcia, 1987), pp. 328 y ss. El aumento de población también nos viene señalado por la serie de obras de ampliación de la iglesia que se llevaron a cabo en estos años; en 1948 se reedificó la iglesia de Santa María siguiendo la pauta por la que se construyeron la mayor parte de estos templos parroquiales de la comarca - un cuerpo de tapiería con arcos atravesados de cal y canto-, que en 1521 y 1526 se vio enriquecida con una capilla mayor de cantería.

6 La llegada de colonos al noroeste del Reino de Murcia llevó consigo una nueva reorganización y reparto del territorio en función de planteamientos puramente ganaderos con concesiones de derechos sobre pastos en dehesas de uso común, o las dadas para cultivos agrarios de uso privativo hasta recogida la cosecha, o en otras condiciones según numerosas fórmulas. Ver David E. VASSBERG, La venta de tierras baldías. El comunitarismo agrario y la Corona de Castilla durante el siglo XVI (Madrid, 1983), pp. 27 y ss.

7 André VAuchez, La sainteté en Occident aux derniers siècles du Moyen Age d'après les procès de canonisation et les documents hagiographiques (Roma, 1981), pp. 254 y ss. 
El culto a la Virgen María -que desde el Concilio de Efeso, en el siglo $\mathrm{V}$, poseía el título de theotokos, por el que se la situaba por encima de la condición ordinaria de los humanos-, al final de la Edad Media, se vio incurso en un movimiento que tendía a enaltecerla en todos los sentidos, al tiempo que presionaba a la autoridad eclesiástica para que confirmase como verdadera la creencia en la Inmaculada Concepción. Se la unía al culto debido a los santos y mártires de los primeros siglos del cristianismo que hacían su aparición ahora, como especializados en su labor de mediadores en determinados males naturales y enfermedades, dentro de lo que podemos ver como una recuperación histórica de un cristianismo anterior, ante el que la ocupación musulmana se admitía ahora como un paréntesis impuesto que debía ser olvidado y obviado ${ }^{8}$. Y junto a todo ello se reafirmaba la devoción a la Cruz y a la Pasión de Cristo, nuevamente propagadas por los franciscanos, como claro contrapunto de esperanza del sentimiento de angustia que en numerosas ocasiones había atenazado la psicología popular durante siglos ante situaciones desastrosas 9 . Sirviendo de estandartes a la labor de los misioneros en la cristianización de las masas populares de Europa, la devoción a la Cruz, la Virgen y los santos y mártires, comenzó a propagarse el cristianismo en una nueva etapa de ocupación del suelo europeo al tiempo que lo sacralizaba.

En una época de exaltación religiosa como fue ésta del final del siglo $\mathrm{XV}$, todos estos sentimientos y creencias llegaron a Moratalla en un momento que hemos de ver como singular, al darse de manera manifiesta el impulso que llevó a constatar en la naturaleza cercana - paisaje separado y medianil de otro mundo también enemigo- la ampliación del lugar sagrado hasta entonces circunscrito al templo de la villa, en un movimiento espiritual que condujo a que el pueblo lo ocupase dentro de un impulso que le era verdaderamente propio. En muchos lugares de la geografía española, conforme habían sido recuperados por el avance de la reconquista, se habían levantado templos, ermitas y santuarios ${ }^{10}$. Y en ellos, desde el

8 Pedro DE la Vega, La vida y pasión de nuestro Señor Jesucristo, o las historias de las festividades de su Santísima Madre con las de los Santos Apóstoles, mártires, confesores y virgenes (Zaragoza, 1521).

9. Deleruelle, «Le crucifix dans la piété populaire et dans l'art, du VI au XI siècle», Études ligériennes d'Histoire et d'Archeologie médiévale (Auxerre, 1975), pp. 133 y ss. P. ThовY, Le crucifix des origines au Concile de Trente (Nantes, 1959).

10 Una buena síntesis reciente en Fernando de OlAGUer Feliú, El arte medieval basta el año mil (Madrid, 1989). Iglesias del período gótico-arriano (hasta 586), pp. 41 y ss., del período gótico-católico (586-711), pp. 67 y ss. Período en torno al año mil, en Aragón y Navarra en pp. 300 y ss.; en Castilla, en pp. 307 y ss. V. LAMPÉREZ Romea, Historia de la Arquitectura Cristiana Española en la Edad Media, Vol. I (Madrid, 1930). 
siglo XI —como consecuencia del impulso dado por concilios y sínodos al uso de imágenes de la Virgen, santos y mártires, junto a otras figuras y símbolos de significados más o menos crípticos-, fueron apareciendo dentro de los presupuestos artísticos de lo que sería llamado arte románico ". Hasta entonces, como hemos apuntado, el motivo aducido con mayor frecuencia para erigir una iglesia o ermita en honor de un mártir ha sido contar con el hecho (bajo visos de leyenda, siempre difícil de estimar en su autenticidad, pero no por ello menos aceptado con fuerza) de haber encontrado en el lugar indicado algún sepulcro o reliquia que lo sacralizaba ${ }^{12}$, o con la presencia de algún anacoreta que se había retirado a aquel lugar para llevar vida de oración ${ }^{13}$. Sin embargo, durante los siglos comprendidos entre el XII y XIII, los motivos que habían propiciado que se levantasen estos centros de culto fueron cambiando sensiblemente, ya que ahora el motivo principal fue la aparición de la Virgen, y de imágenes suyas, a pastores y labradores y también a ascetas entregados a sus devociones en aquel lugar, con los que se identificó la masa popular al creer que se daba en ellos (personas santas) una relación directa con la gracia divina que, a su vez,

11 Continúa siendo muy útil, de l'Abbé Corblet, Vocabulaire des symboles et des attributs employés dans l'Iconographie chrétienne (1. ed. 1877, reedición en 1931); así como de l'Abbé AUBERT, Histoire et Théorie du symbolisme réligieux avant et aprés le Christianisme (Paris, 1910), 4 vols. Ver Juan FERRANDo RolG, Iconografía de los santos (Barcelona, 1950); del mismo autor, Simbología cristiana (Barcelona, 1958). Louis REAU, Iconographie de l'art chrétien (Paris, 1958).

12 Justo Fernández Alonso, La cura pastoral en la España romanovisigoda (Roma, 1955), pp. 372 y ss. Carmen García RodríGuez, El culto a los santos en la España romana y visigoda (Madrid, 1966), pp. 175 y ss. H. DeleHAYE, Les origins du culte des Martyrs (Bruselas, 1923). Ángel Fábrega GraU, Pasionario Hispánico (siglos VI al XI) (Madrid, 1953), pp. 32 y ss.

13 William A. Christian, «De los santos a María: panorama de las devociones en santuarios españoles desde el principio de la Edad Media hasta nuestros días», Temas de Antropología Española, C. Lison Tolosana (ed.) (Madrid, 1976), p. 57. También, del mismo autor, Apariciones en Castilla y Cataluña (siglos XIV-XVI) (Madrid, 1990), pp. 25 y ss. Santuarios como el de Monserrat, Valvanera, Nuria, de la Peña de Francia, de la Esperanza... tienen su origen en la presencia de ermitaños u hombres santos. Ver, de A. LINAGE CONDE, «El monacato español hasta el Concilio de Trento», Repertorio de la Historia de las Ciencias Eclesiásticas de España (Salamanca, 1973), pp. 103 y ss. Posteriormente continuó produciéndose este hecho en numerosos lugares, como encontramos en el mismo Reino de Murcia, en los siglos XVI y XVII en uno de los montes próximos a su capital, en el lado de Levante que fue conocido por la Nueva Tebaida o la Tebaida murciana, por la numerosa presencia de ermitaños que se retiraron del mundo a este paraje, donde después se levantó el santuario de la Virgen de la Fuensanta. Como es bien sabido, la vida eremítica, que a su vez dio lugar a la existencia de una picaresca, se trató de hacer desaparecer en tiempos de Carlos III. 
podía dar como resultado la obtención de abundantes bienes para la comunidad. El ermitaño fue visto como el intermediario con la divinidad que sacralizaba el campo próximo en un lugar muy preciso ${ }^{14}$. El ejemplo más hermoso que nos dice de la propagación del culto a la Virgen sobre numerosas imágenes en esta época es el de Las Cantigas de Alfonso $\mathrm{X}$ unidas a todo tipo de milagros y leyendas piadosas, a la vez que nos informa de que en toda la España cristiana de su tiempo ya se habían levantado santuarios marianos con imágenes muy características ${ }^{15}$.

Durante los siglos de la baja Edad Media, el número de apariciones de este tipo se multiplicó de tal forma en los más diversos lugares de Europa que movió a que interviniese la Iglesia para tratar de regularizarlos conforme a unos principios doctrinales. En el Concilio Lateranense de 1516 se dictaminó que toda aparición declarada a la autoridad eclesiástica local debía quedar en suspenso en cuanto a su aceptación hasta que no fuese examinada por personas sabias que la asumiesen como tal. Se esgrimieron dos razones para ello: en el plano de la fe, por la necesidad de proteger a la Iglesia de la proliferación de visiones en una época oscura, pietista e inquieta, en donde era necesario observar gran prudencia; y en el plano del gobierno, porque estos acontecimientos y mensajes locales corrían el peligro de estorbar el gobierno de los

14 E. Delaruelle, La piété populaire au Moyen Age (Turín, 1975). Los ejemplos de apariciones de la Virgen en España son numerosísimos, como vemos en las leyendas de N. S. del Pueyo en Barbastro; N. S. del Camino en León; N. S. de Angosto en Álava; N. S. de la Luz en Santander, etc. Véase Jesús Polo Carrasco, «Las apariciones de Nuestra Señora y la Religiosidad Popular», Scripta de Maria, X (1987), pp. 343 y ss. I. Bengoechea IZAguirRe, «Las apariciones de la Virgen» en «Sociología Mariológica Española», Enciclopedia Mariana Posconciliar (Madrid, 1975), pp. 263 y ss. Javier IBÁÑEZ-FERnANDO MENDOZA, «Las apariciones en los orígenes de los santuarios marianos. Presencia viva actual de María en sus santuarios», Scripta de María, X (1987), pp. 321 y ss. Sobre el término ermita, véase Robert RICARD, «Ermita: ermitage, sanctuaire?», Mélanges de la Casa de Velázquez, XVI (1980), pp. 451 y ss. Es interesante lo que dicen los Sínodos de esta época: ver Constituciones synodales del Obispado de Carthagena, por Hieronymo MANRIQUE DE LARA, obispo de Carthagena. Sínodo celebrado en diciembre de 1583. Valladolid, 1590. Sobre ermitas en fol. 158 y vto.

15 Sobre las imágenes de la Virgen en las miniaturas de los códices de Las Cantigas véase, de José GUerRero Lovillo, Las Cantigas, estudio arqueológico de sus miniaturas (Madrid, 1949), pp. 266 y ss. Es interesante tener presentes las imágenes de la Virgen reunidas con motivo de la exposición Las edades del hombre, Valladolid, 1989. Catálogo de la Exposición (Valladolid, 1988), pp. 130 y ss. De la iconografía francesa dedicada a la Virgen en los siglos XIII, XIV y XV en Maurice VlobeRG, La Vierge et l'enfant dans l'art français (Grenoble, 1933), 2 vols. 
obispos y de la autoridad suprema ${ }^{16}$. En el Concilio de Trento, en 1563, toda esta doctrina sobre apariciones y milagros fue confirmada plenamente, al observarse que el conocimiento humano en este mundo es obtenido por medio de signos que llevan a la captación de una visión de la realidad misma sobre los más diversos modos, entre los que están los que permiten las fuerzas sobrenaturales.

Sin duda alguna, es en este momento de encrucijada del pasado de Europa donde debemos señalar una separación entre la doctrina religiosa puramente oficial y la sostenida por el pueblo, desde una fe que podemos considerar como un tanto ingenua, pero que no quita nada para sentirla como manifestación de una gran complejidad. Por un lado, la evolución histórica de las estructuras políticas y eclesiásticas había hecho que la consideración de gens sancta recayese únicamente sobre la parte escogida e institucional del conjunto social o sociedad cristiana. Preferentemente estaba establecido que podían ser santos los papas, los obispos, los sacerdotes, los frailes de las diversas órdenes ${ }^{17}$. El resto, los fieles que formaban la masa del pueblo, en su inmensa mayoría, quedaba como un cuerpo pasivo con la misión de ser meros observadores de los praecepta Dei, a la vez que se debían someter sin la menor crítica a la disciplina que emanaba de la autoridad eclesial ${ }^{18}$. El pueblo pasó a estar compuesto por los laicus y laicalis, que era lo mismo que decir los que no estaban destinados a ser santos. En el siglo XI, los fieles que formaban la masa popular todavía

16 Las relaciones con los laicos quedaron establecidas y reguladas directamente a través de los Sínodos que marcaban las directrices de la actuación pastoral: I. SANZ SANCHO, "La religiosidad del clero y del pueblo en los sínodos murcianos del siglo XIV», Carthaginensia, V, núm. 7-8 (1989), pp. 31 y ss. Sobre los laicos, pp. 75 y ss. L. Pascual Martinez, «Los Sínodos de la Iglesia Cartaginense: Siglo XV», Miscelánea Medieval Murciana, XIV (1987-1988), pp. 187 y ss. Ver J. SÁnCHEZ Herrero, «Los concilios provinciales y los sínodos diocesanos españoles 1215-1550», Quaderni Catanesi di Studi Classici e Medievali, III (1981), pp. 113 y ss., y IV (1982), pp. 111 y ss.

17 Ver en André VAuchez, La saintété..., op. cit. Sobre la tipología de los santos, en pp. 302 y ss. La de los obispos, en las pp. 358 y ss. La de los sacerdotes, en pp. 388 y ss. La de los miembros de las órdenes mendicantes, en pp. 410 y ss. Sobre la evolución del concepto de santidad del siglo XII al XV en pp. 449 y ss.

18 La masa popular, sumamente pobre, fue dejada a un lado, con la esperanza de alcanzar la gloria en el otro mundo por la bondad infinita de Dios y, por otro lado, la predicación de la pobreza no fue bien vista por una parte importante de la Iglesia, llegándose incluso a tenerla como fuente posible de llevar a la herejía; ver $\mathrm{T}$. MANTEUfFel, Naissance d'une bérésie, les adeptes de la pauvreté volontaire au Moyen Age (Paris-La Haya, 1970). Recordemos que San Francisco de Asís también fue acusado y casi condenado por su doctrina de rechazo de la manifestación de la riqueza, teniendo que recurrir a medidas radicales la Iglesia de Roma para doblegar a sus seguidores más 
eran considerados rusticus y pagani, aunque ya podían entrar en determinadas consideraciones al establecerse en ellos una gradación de méritos en cuanto a la perfección, ocupando el primer puesto las vírgenes, a las que seguían los viudos ${ }^{19}$. Sin duda alguna, hemos de ver como reacción ante esta situación el movimiento de interioridad y de espiritualidad que se produjo en la masa popular de toda Europa, que condujo a la creación de un sistema religioso acorde con su capacidad y sensibilidad para situar su posición en el mundo y en la naturaleza, y que pronto se manifestó de manera imparable, viniendo a hacerse presente en mil manifestaciones dentro de un paralelismo que fue visto con recelo y desconfianza por la autoridad eclesiástica. Es aquí, en este cuerpo de creencias y sentimientos, orientado hacia una comprensión de la divinidad desde las flacas fuerzas del hombre no docto en abstracciones, donde debemos ver el nacimiento de lo que después se ha llamado religiosidad popular que vino a completar la aceptación que observaron desde un segundo plano de la enseñanza de los principios y ritos religiosos, hermanada con una resignación ante las enfermedades y la pobreza ${ }^{20}$. Como se nos ha dicho, la Iglesia, que había favorecido la feudalización de la sociedad dándole un verdadero apoyo espiritual y una auténtica consagración, encontró en los movimientos laicos, que se organizaron como focos de resistencia desde los que manifestaban

recalcitrantes e intransigentes en los presupuestos de esta doctrina, los espiritualistas. Poco después, por mandato del papado, se levantó en Asís, donde estaba sepultado el santo, un templo adornado con las más ricas pinturas del artista más cotizado de aquella época, Giotto, que, sin duda alguna, el santo no habría consentido. Sobre ello, ver Jean GiMPEL, Contre l'Art et les artistes (Paris, 1968), p. 23.

19 Oronzo GIORDano, Religiosidad popular en la Alta Edad Media (Madrid, 1983), p. 255. El problema de la religiosidad popular es sumamente complejo, ya que debemos entenderlo, también en épocas posteriores a las medievales, como un fenómeno que no debe remitir siempre al medio rural, como ha señalado Antonio DomfNGUEZ ORTIZ en «Iglesia institucional y religiosidad popular en la España barroca», La fiesta, la ceremonia, el rito (Granada, 1990), p. 9. Desde el aspecto de la metodología, ver R. MANSELli, La religion populaire au Moyen Age, problème de méthode et d'bistoire (Montreal-Paris, 1975).

20 Para algunos autores como R. MANSELLI, la religiosidad popular debe ser entendida dentro de la unidad del hecho religioso que se presenta en la experiencia humana como una sola realidad, lo que llevaría, en caso de tomarla por separado, a un error metodológico que invalidaría todo intento de acercamiento a su comprensión como fenómeno tipificador. Para este autor, hay que hacer una distinción entre una religiosidad culta que tiende a estructurarse sobre una sistematización conceptual de nociones dadas por la revelación de la Palabra cristiana, mientras que la religiosidad popular es una manifestación espontánea de sus sentimientos frente al misterio del mundo y del hombre en cada tiempo. Ver R. MANSELli, La Réligion Populaire au Moyen Age. Problèmes de méthode et d'bistoire (Montreal, 1975), pp. 17 y ss. 
su propia manera de ser, una verdadera colaboración que avisaba del sentido que procuraba el devenir de los tiempos y a la vez un peligro latente de resistencia que podía conducir a la aparición de herejías; por más que los movimientos auspiciados por los laicos en aquellos tiempos no tratasen de debatir un problema teológico sino eclesiológico, como quedó de manifiesto más adelante cuando éstos apoyaron los movimientos auspiciados por las órdenes religiosas, que predicaron la reforma de la Iglesia en su renovación moral, social económica y religiosa junto a la pobreza y humildad como virtudes y fuente de vida espiritual ${ }^{21}$. Por todo ello, si consideramos el movimiento que llevó a la aparición de ermitas en el paisaje europeo de los siglos bajomedievales, vemos que se fundamentaron en apariciones o en el hallazgo de una imagen por un pastor o labrador, o por el primer ermitaño que estaba a su cuidado; lo que es lo mismo que decir que de miembros que componían el laicado y, por lo tanto, considerados por la autoridad como excluidos de poder participar de revelaciones sobrenaturales. Sobre estas personas, a veces videntes, que jugaron el papel de intermediarios humanos entre el pueblo y la divinidad ${ }^{22}$, y también tenidos por los sucesores de los santos mártires cuyos restos habían sido encontrados anteriormente en un sepulcro, cayó el sentimiento de que eran capaces de procurar la acción benefactora de las reliquias encontradas de manera milagrosa. El pueblo, junto a ellos, sacralizó las tierras que trabajaba con penoso esfuerzo y poco fruto, y, en consecuencia, muchos de estos ermitaños vinieron a ser considerados por el pueblo como auténticos santos, que eran vistos de modo muy distinto a los que la Iglesia continuó canonizando y, como tales, poniendo como ejemplo de un modo oficial en el santoral ${ }^{23}$, por más que también los tomase una y otra vez como ejemplos próximos en sus predicaciones y en las colecciones que se reunieron bajo el nombre de speculum, liber precum, formula bonestae vitae, liber scintillarum, etc., junto a pasajes bíblicos y referencias a santos reyes en función de la autoridad que confería la costumbre.

Las leyendas que refieren apariciones, con profusión de detalles como gestos, lágrimas, mensajes, de imágenes de la Virgen, que comenzaron a sucederse con suma frecuencia en los más diversos lugares, nos hablan del grado de consideración y aceptación que tuvieron en la mentalidad

21 R. MORGHen, «Aspetti ereticali dei movimenti religiosi popolari», I laici nella "Societas christiana" dei sec. XI-XII. Atti della III Settimana Inter. di Studio (Mendola, 1965 y Milano, 1968).

22 Ver H. Delehaya, Les légendes hagiographiques (Bruselas, ${ }^{4} 1955$ ).

23 Ver André VAUCHEZ, L'idée de sainteté aux XIII et XIV siècles d'après les procès de canonisation et dans l'opinion des fidèles (Paris, 1961). 
popular. Como nos recuerda William A. Christian, después de una aparición, una imagen representta y respalda una presencia real, una epifanía ${ }^{24}$. Los santuarios, hasta el siglo XI, en gran parte, habían fundamentado su existencia en la posesión de reliquias o en la aparición milagrosa del cuerpo de un mártir o santo. Pero ahora, las imágenes - que hasta ese momento, siguiendo disposiciones de los primeros Concilios, como el de Elvira en 300-306, habían estado prohibidas expresamente, ante el temor de que impulsaran a la continuidad de muchos hombres en la superstición y por las ansias de borrar toda tendencia a adorar ídolos, como había ocurrido en la etapa romana de la Península - podían ser mostradas sin ninguno de estos riesgos. La influencia de la Iglesia de Oriente guió a la piedad popular y a la Iglesia hacia la consideración de la presencia de las imágenes en los templos, así como a la sacralización de la campiña. La imagen de la Virgen María fue apareciendo unida, en las comunidades rurales, a determinado simbolismo que la asoció con fuentes, cimas de montañas, cuevas y grutas, dentro de la caracterización de la concepción del mundo de la vida agrícola-pastoril. La localización del culto de la Virgen, de la Cruz y de algunos santos, en lugares muy elevados (como la cima de una montaña desde siempre vista como algo singular), o de características definidas (como una fuente o una arboleda), tenían sus antecedentes en la etapa del mundo precristiano, al reflejar contactos con las fuerzas de la naturaleza más allá del control del individuo o de la comunidad ${ }^{25}$, por más que no debamos entender esto de manera determinista en todos los casos al considerarlo, ahora, en la Baja Edad Media, como una continuación lineal, sino, también como una reacción propia de unos hombres destinados a vivir en unos lugares muy limitados y en constante lucha con la naturaleza amenazadora y arbitraria. Su aceptación por parte de la Iglesia, desde un sincretismo manifiesto, se puso también de manifiesto en estos momentos. Al mismo tiempo, principalmente en las ciudades, el culto a la Virgen María fue estructurándose y divulgándose en la sociedad española a través de cofradías ${ }^{26}$, junto a una literatura en castellano sobre su figura ${ }^{27}$.

24 William A. Christian, «De los santos...», op. cit., p. 61.

25 F. RAPp, L'Eglise et la vie religieuse en Occident à la fin du Moyen Age (Paris, 1971), pp. 32 y ss. W. A. CHRISTIAN, «De los santos...», op. cit., p. 66. Ver VV.AA., Evangelizzazione e culture (Roma, 1976), 2 vols., con artículo de R. MANSELLI, «La conversione come evangelizzazione nell'Alto Medievo», II, pp. 160 y ss. entre otros.

26 En el Reino de Murcia encontramos una Cofradía en Murcia 1515 con iglesia propia terminada en 1582. En Caravaca se fundó la cofradía de la Inmaculada en 1532, en la iglesia de la Concepción, contando con hospital. En 1538 se constituyó en Cehegín la cofradía de la Inmaculada Concepción, con iglesia y hospital. Ver Pedro Lozano Berenguer, «Las Cofradías de la Purísima en España», La Virgen María en la religiosidad española del siglo XVI (Salamanca, 1980), pp. 323 y ss.

27 En 1495 se publicó, en Zaragoza, el libro de Martín MARTfNEZ DE AMPIER, Triumpho de María, primera obra de título mariano impresa en España. En 1511, en 
En los campos abiertos y montuosos del noroeste murciano, en aquellos días de encrucijada de la Edad Media con el mundo moderno que, como sabemos, supuso también el principio de una expansión en paz, todas estas ideas y sentimientos religiosos, que desde hacía tiempo venían circulando por el suelo europeo, alcanzaron, como veremos más adelante, unas manifestaciones muy peculiares.

En la vecina villa de Caravaca, lugar principal como posesión de la Orden del Temple en una etapa anterior, de castillo con fuertes defensas y Encomienda de la Orden de Santiago, desde hacía tiempo, venía adorándose a la Santa Cruz aparecida milagrosamente según rezaba la tradición y levantada como arma singular contra un enemigo amenazador y próximo. Ahora, en Moratalla, como veremos, la Cruz se hizo presente también, aunque dentro de un sentido completamente distinto, al mostrarse como benefactora y protectora de cuantos moraban en su amparo y en sus campos. $Y$ junto a la Cruz, la imagen de la Virgen se apareció en un lugar próximo, abriendo aún más el ámbito de la parroquia de intramuros consagrada a Santa María, junto a otras ermitas dedicadas a santos.

Sevilla, de Juan de Robles, La vida y excelencias e milagros de santa Anna y de la gloriosa nuestra Señora santa Maria fasta la edad de quatorce años. En 1512, en Valencia, Mariale del dominico SANCHO PORTA. Ver Federico DelClaUX, «Bibliografía mariana española del siglo XVI», Scripta de María, I (1978), pp. 40 y ss., y Laurentino M. HeRRán, «La devoción popular a María en el siglo XVI», La Virgen María en la religiosidad española del siglo XVI (Salamanca, 1980), pp. 219 y ss. Para los Flos Sanctorum de Pedro DE LA Vega, p. 232, de Alonso DE Villegas, p. 236. 


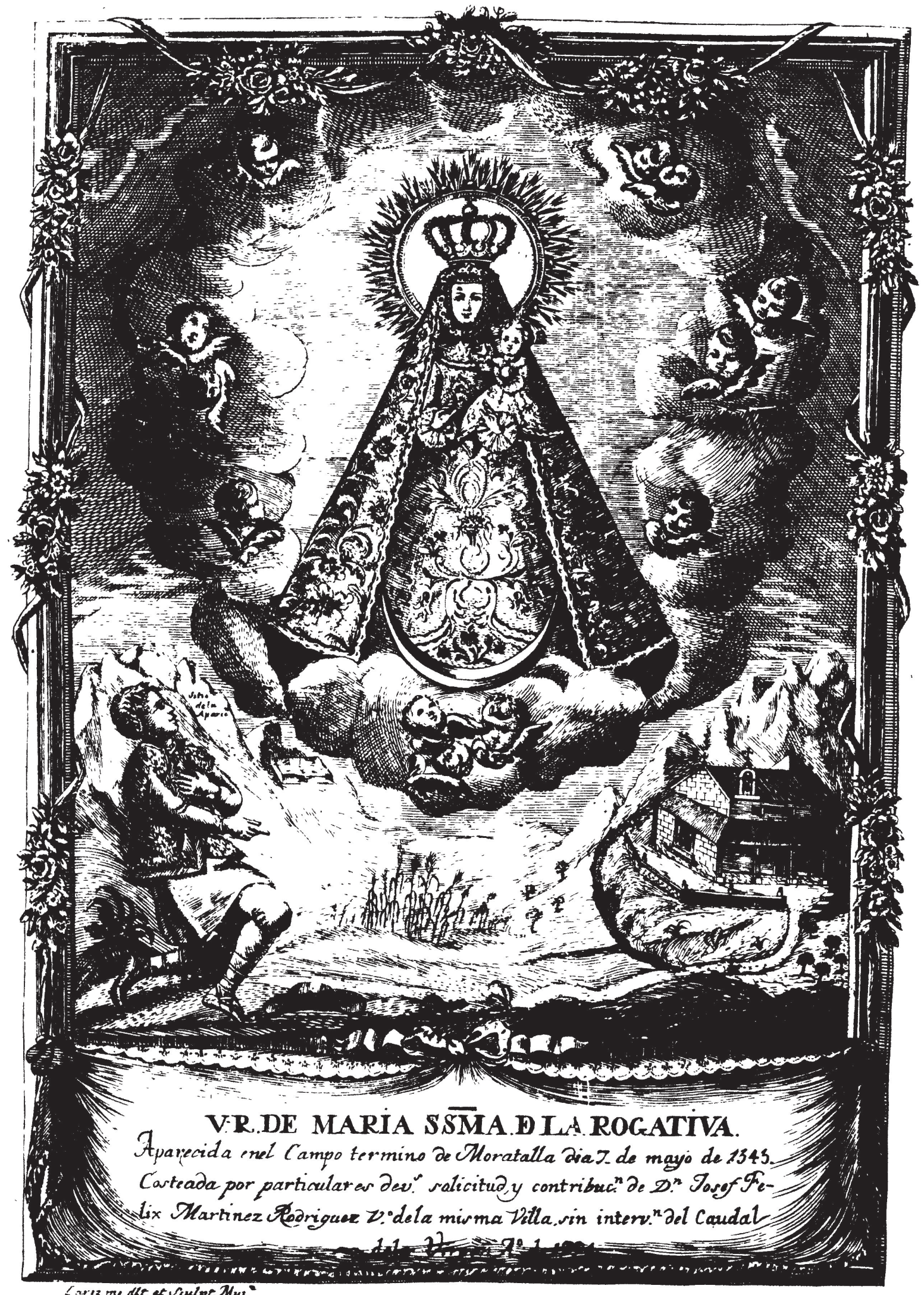

Grabado de Nuestra Señora de la Rogativa, dibujado y grabado por Lariz, Murcia, año 1794. 


\section{APARICIONES Y ERMITAS}

Nos refiere la tradición que, el 19 de abril de 1493, un labrador manco, llamado José Ruiz Sánchez, de las Casas de Aledo en el Campo de San Juan, guiando una mula en la que llevaba una carga de leña y un talego de sal, marchaba a Moratalla por el camino que acercaba al Salero del monte Zacatín, cuando, al pasar por el sitio conocido por Monte Benamor, vio un gran resplandor de fuego en cuyo centro estaba Jesucristo. El hombre, sobrecogido, cayó de rodillas en tierra y escuchó las palabras que le decía aquel ser divino ordenándole que fuese a Moratalla y dijese a las autoridades que era su voluntad que en aquel lugar levantasen un santuario que debía ser invocado por el nombre de Jesús.

Cuando el labrador llegó a la villa y refirió lo que le había sucedido se encontró con que no le creían, lo que le hizo volver al lugar del «aparecimiento» donde explicó a Jesús que no habían servido de nada sus palabras. Entonces Jesús le dijo: «Vuelve al pueblo y, puesto que eres manco, enseña tu brazo». José Ruiz Sánchez se reconoció y vio que estaba curado de su manquedad y, ya en el pueblo, a la vista del milagro obrado por Jesús, todos creyeron que era verdad lo que había referido. En el acto, el Comendador de la Orden de Santiago, el cura párroco, el escribano del Concejo $\mathrm{y}$ un número grande de vecinos acudieron al lugar indicado con el fin de adorar al Hijo de Dios venido a aquellas tierras en persona, como hicieron al encontrar todavía el resplandor divino en la lejanía y que fue disipándose poco a poco sin que nadie llegase a ver la figura de Jesucristo.

Poco después comenzó a construirse una ermita en un lugar pero, al resultar que no era el preciso en que había sucedido la aparición, todo cuanto se adelantaba durante la faena del día se caía por la noche, lo que hizo que se trasladasen dichas obras al verdadero sitio del aparecimiento, viniendo a suceder entonces que por la noche dichas obras crecían ${ }^{28}$.

La ermita, según nos fue descrita por los «visitadores» de la Orden de Santiago en 1507, «era una obra muy bien obrada». En su altar mayor estaban pintadas

28 Alfredo RuBio HEREDIA recoge la leyenda del aparecimiento de Jesucristo en su libro Cosas de Moratalla (Moratalla, 1915), pp. 161 y ss., según nos dice, de un manuscrito anónimo del siglo xviII. Una versión idéntica la encontramos en el libro de J. Robles CoRvalán, Historia del mysterioso..., op. cit., fol. 119 b. Este autor nos dice que Jesucristo se había aparecido en Moratalla para estar cerca de su Cruz. El libro de Robles Corvalán es de 1619. 
de pinzel la ymagen de Nuestro Señor e de San Juan e de la Madalena, con su guardapolvo. Ay en la dicha yglesia dos altares; en el altar maior esta la imajen de Nuestra Señora de bulto, en las espaldas vna cortina morisca colgada, e junto con el dicho altar vn lienço pintado con la quinta angustia e otro retablo pequeño con la Veronica e otro lienço de la misma figura ${ }^{29}$

En otro altar había un retablo de madera con el misterio que en dicho lugar había sucedido. Más tarde, se instaló en ella un ermitaño o santero con el cargo de cuidarla, del que sabemos que pasaba los días vagando por los campos y cañadas pidiendo limosna y orando, o recibiendo las ofrendas de los fieles. En dicha ermita sólo había culto cuando llegaba a ella algún sacerdote a decir misa, y la solemne función religiosa que se hacía junto a la romería de los vecinos de Moratalla el 19 de abril, fecha del aniversario de la aparición. Más tarde, en 1585 ó 1589, por iniciativa del padre Comendador o guardián del Convento de Mercedarios de Lorca, se levantó en el lugar del monte Benamor un convento, quedando la primitiva ermita situada en la parte norte del nuevo edificio, con la puerta hacia el mediodía, pasando a ser utilizado por los frailes, posteriormente como cementerio con la cerca de sus mismos muros ${ }^{30}$. En 1808, el convento sufrió el asalto de un cuerpo de ejército de Napoleón en Andalucía, que lo incendió, quedando completamente destruido. La imagen de Jesucristo se salvó por encontrarse en la parroquia de la villa para las funciones anuales que se le hacían en la parroquia, después de que se verificase un rito por el que se levantaba por el escribano una escritura llamada pleito bomenaje en que se fijaban las condiciones de entrega de la imagen y de quienes avalaban su permanencia fuera de la iglesia del convento.

Con el «aparecimiento» de la imagen de Jesucristo en el monte Benamor, en las proximidades de Moratalla, se cumplía el primer paso para

29 Cuaderno de la visita realizada a la villa de Moratalla por Diego de Córdoba y Alonso Martinez, visitadores de la Orden de Santiago para el reino de Murcia (AHM, Ordenes Militares, Mss. Santiago 1072 C, pp. 169 a 209) en Miguel RodrfGuez Llopis, Documentos para la Historia Medieval de Moratalla (Murcia, 1988), p. 194.

30 A. Rubio Heredia, Cosas de..., op. cit., p. 164. En el acta de la sesión del Concejo de Moratalla de 25 de junio, en su folio 326 y siguientes del libro capitular de 1584 (hoy desaparecido), se detallaban las condiciones en que se accedió al establecimiento de los frailes de la Merced, que vienen a ser las usuales en estos casos, como que se hacía «por voluntad de dicho Concejo y que en ninguna manera por lapso de tiempo, aunque sea inmemorial, puedan adquirir ningún derecho, así en posesión como en propiedad en la dicha ermita y edificios que se hicieren». También se limitaba el número de frailes a seis, siendo uno de ellos predicador, dos de misa, y los demás a contento del Comendador. Se imponía que no podían pedir limosna por la condición obstiatim, o de puerta en puerta, si no era domingo o fiesta de guardar.. El acta en pp. 166 y ss. 
dotar a su campo, bien delimitado frente a pretensiones de Yeste, Socovos, etc. de la presencia de lo sobrenatural, sacralizándolo, dentro del sentido que la nueva religiosidad laica que emergía trataba de imponer, y de una separación más o menos declarada de lo que venía a significar la figura de Jesucristo en relación con la presencia de la Cruz en la próxima Caravaca, tanto como protectora de sus habitantes cuanto como guía del brazo militar que se guarnecía en su castillo ${ }^{31}$. La persona de Jesucristo había descendido a las tierras que ahora comenzaban a cultivar los hombres de Moratalla para bendecirla y protegerla, aunque según parece, la leyenda de esta aparición se debió de mostrar un tanto endeble desde el principio, pues sólo se formalizó en época posterior sobre documentos con testimonios que la avalaron. El primer testimonio escrito que nos ha llegado es el del escribano Antonio López Navarro que ejerció en la villa en fechas cercanas a la llegada de los frailes de la Merced. Según este documento, José Ruiz Sánchez, en el momento de la aparición, vio una figura que no supo distinguir con certeza si era un fraile o Jesucristo como se dijo. Dicha figura tenía «una cruz coloreada en los pechos y un báculo de oro en la mano, tan grueso como un dardo y una cruz en la punta alta». Por último, se daba cuenta en el escrito de que se habían hecho averiguaciones de los milagros «que desde luego obró a fecho e face, sanando enfermos, cojos e quebrados e de otras enfermedades» la imagen de Jesucristo que se guardaba en la ermita ${ }^{32}$. Más adelante, a fines del siglo XVII, en 1685, para salvar las posibles dudas que el caso manifestaba, todavía se trató de fijar el aparecimiento de Jesucristo en Benamor con el testimonio de diez personas calificadas, como el del licenciado y presbítero, que ejercía de Comisario del Santo Tribunal de la Inquisición, que refirió bajo legal juramento varios milagros, al tiempo de describía la procesión que se hacía desde muchísimo

31 Ver R. Amador DE los Rfos, «Riquezas perdidas: la Santa Cruz de Caravaca y su capilla en los últimos años del siglo XV», Revista de Archivos, Bicliotecas y Museos, XVII, pp. 226 y ss. Sobre la aparición de la Cruz en Caravaca hay una amplia bibliografía; ver el libro ya citado de J. Robles Corvalán, y de A. MARf́n De Espinosa, Memorias para la Historia de la Ciudad de Caravaca (y del aparecimiento de la Santísima Cruz) desde los tiempos más remotos hasta nuestros días e ilustrados con notas históricas (Caravaca, 1856) (2.: ed. en facsímil Barcelona, 1975); Q. BAS y MARTf́nEZ, La Santísima Cruz de Caravaca. Su aparición, santuarios, monumentos, etc. (Játiva, 1887) (2." ed. Caravaca, 1906); Vicente DE LA FUENTE, «La Santa Cruz de Caravaca», Boletín de la Real Academia de la Historia, IX, pp. 319 y ss.; F. Parayuelo, Caravaca de la Cruz. Historia $y$ leyenda (Madrid, 1967); Gregorio SÁNCHEZ Romero, El campo de Caravaca (Murcia) (Caravaca, 1987).

32 Sobre la imagen de Jesucristo que había en la ermita se argumentó la leyenda de que el artista que la hizo falleció de repente al terminarla para que no volviese a hacer otra tan hermosa. A. Rubio Heredia, Cosas de..., op. cit., pp. 182 y 185. 
tiempo atrás llevando la imagen de Jesucristo alrededor del convento de la Casa de Cristo con acompañamiento de la parroquia, villa y fieles y de la función religiosa que se celebraba para bendecir los campos ${ }^{33}$.

Junto a la aparición de Jesucristo en Benamor, debemos exponer las leyendas que nos refieren la de la Virgen de la Rogativa, sucedida, según unas versiones, en 1533, en unos momentos en los que en las relativamente cercanas tierras de la Alpujarra se desarrollaba la rebelión de los moriscos que había llevado a que aparecieran por las tierras de Moratalla numerosos hombres y mujeres huidos, desnudos y hambrientos, solicitando que por caridad les dieran algún socorro.

Era el 5 de mayo de 1535, víspera de la fiesta de la Ascensión de Jesús, cuando Ginés Martínez de Cuenca, un mozo de unos veinte años, se encontraba apacentando unas vacas de su labor en la cañada del Serbalejo, sitio distante de Moratalla unas seis leguas hacia poniente, cuando rompió a llover copiosamente en medio de una tormenta cargada de rayos que le obligó a buscar amparo para él y su ganado en un hato de pastores que había cerca; allí pasó la noche junto al rescoldo de una lumbre cuando en sueños vino a turbarle repetidas veces una visión en la que aparecía la forma de una mujer, lo que al final, "por inquietarle su imaginación tan fantásticas quimeras», hizo que se despertase muy temprano llegando a preguntar a sus compañeros de refugio si había junto a ellos una mujer, a lo que le respondieron, un tanto extrañados, que no. Entonces, para ver lo que había profundizado la lluvia de la noche en la tierra, marchó a sus tierras de la cañada, donde pronto vio llamada su atención por un trozo de sembradura que tenía las espigas completamente granadas, lo que le hacía tomar un fuerte contraste con el resto de la sementera, tardía y floja. El muchacho, viendo aquello, exclamó: «¡Válgame nuestra Señora!», pero tan pronto hubo acabado de decir aquellas palabras, cuando una paloma blanca cruzó ante él, lo que hizo que tomase una piedra y se la tirase. Y en aquel mismo instante, todo el ámbito se iluminó y desde el cielo, entre nubes flotantes y rodeada de pequeños angelillos, vio descender a la Virgen Santa María cubierta con un manto blanco y con unas pequeñas gotas de sangre manchándole su blanca frente. La Virgen le preguntó: «¿Qué buscas, hombre?». Ginés, absorto, cayó de rodillas y escuchó lo que le decía la Virgen: «Que no tuviese cuidado alguno y que fuese a prevenir a los pobladores de Moratalla de que fuesen más caritativos y hospitalarios con aquellos infelices cristianos que de continuo llegaban a sus puertas en busca de limosnas y amparo. Su Santísimo Hijo estaba indignado por tan mal proceder, hasta el extremo de que estaba dispuesto a privarlos de la lluvia

33 Ibid., p. 183. 
tan necesaria para sus campos; pero ella había intercedido con lágrimas de dolor consiguiendo una tregua a su justo enojo, como había sucedido con la lluvia que por la noche había caído devolviendo a los marchitados campos su frescura». Por último, la Virgen pidió que «en aquel lugar se levantase una ermita con el nombre de Nuestra Señora de la Rogativa, pues no traía otra misión que rogar a su Hijo en bien de los pecadores», previniendo, además, que allí quedaban en señal grabadas sus plantas en la tierra. Después la visión desapareció, confundiéndose aquella nube en las alturas. El muchacho todavía permaneció emocionado y fascinado durante largo tiempo. Por último, se incorporó y marchando maquinalmente se encontró ante la puerta de un cortijo que se levantaba en las cercanías. El mozo, tras hacerse rogar, contó lo que le había sucedido a Ginés Valero, que a su vez lo comunicó a Juan y Pedro Matheo y sus mujeres que se trasladaron al lugar del suceso donde pudieron reconocer desde lejos las señales de los sagrados pies de la Virgen. En los días siguientes, una vez que se había propagado la noticia de la aparición, el alcalde pedáneo del Puerto del Conejo, de donde dependía el paraje del Serbalejo, acudió con varias personas a tomar testimonio directo de Ginés Martínez que, tras vencer su timidez y turbación, acertó a referir cuanto le había sucedido. El acontecimiento se propagó de boca en boca hasta el último rincón de la Encomienda de Moratalla, comenzando a llegar a dicho sitio gran cantidad de cojos, tullidos y enfermos en busca de salud y gracia. La tradición, durante mucho tiempo, refirió que bastaba formar un poco de barro con aquella tierra, donde la Virgen había fijado sus pies, y aplicarlo con verdadera fe al sitio enfermo, para que se sanara en el acto, con admiración de los presentes.

En vista de lo que sucedía, los justicias de Moratalla acordaron, en sesión celebrada por el Concejo el 27 de mayo, que pasase una comisión a informarse con fundamento de lo sucedido, tomando para ello declaraciones a los testigos y reconociendo el sitio, como hicieron detenidamente, viniendo a confirmar cuanto llevamos apuntado, así como la autenticidad de los milagros. Concluidas las diligencias, el escribano de la comisión, Martín Pujol, trasladó informe al Asesor abogado de Caravaca que el 14 de junio evacuó diligencia de notificación al Señor Inquisidor de Murcia, al tiempo que dejaba un traslado auténtico en el Concejo de Moratalla ${ }^{34}$.

Los vecinos de Moratalla, movidos de piedad, muy pronto dieron comienzo a la construcción de la ermita. Todo el mundo participó con su esfuerzo y con la ayuda en materiales, como hicieron unos franceses que se encontraban en aquella sierra sacando madera, que regalaron las tablas

34 Ibid., pp. 225 y ss. 
de la techumbre. Una señora principal de Huesca de nombre doña Teresa y casada con Abaino Genovés, hizo a su costa el retablo de madera, en el que figuraba la imagen de la Virgen de la Rogativa, un crucifijo y varias pinturas de santos, manteles y demás ropas de altar...

La leyenda continúa diciéndonos que, pasados algunos años, sólo una cruz extendía sus brazos desnudos sobre un montón de ruinas, mientras la exuberante vegetación de otras veces sólo era un recuerdo ya que había sido sustituida por una tierra negruzca y reseca que rechinaba al ser pisada. Una noche fría y borrascosa del invierno, una chispa de fuego encendida por descuido de un pastor hizo presa en el seto, y pronto, empujado por el viento, se formó un voraz incendio que convirtió en inmensa hoguera el espeso monte, alcanzando a la ermita. La voz de alarma, que gritaba que la ermita ardía, corrió de cortijo en cortijo, llevando a los labradores a acudir para salvar del fuego a la imagen de la Virgen, que fue depositada en la ermita de Jesucristo. Alfredo Rubio Heredia, recopilador de la leyenda sobre testimonios, según nos dice, encontrados en el Archivo del Ayuntamiento de Moratalla, añade también que, desde aquellas lejanas fechas, todos los años vino haciéndose una solemne fiesta religiosa de romería en la que se cumplían las promesas y ofrendas de los lugareños ${ }^{35}$.

En el siglo XVIII, por testimonio del padre José Villalva y Córcoles, tenemos otra versión de la leyenda, que en parte completa la ofrecida en páginas anteriores, pues aunque sostiene en sus detalles lo hasta aquí visto respecto a la aparición, salvo la fecha, que data en 1545, añade que

Pasado algún tiempo la Virgen volvió a aparecerse a Miguel Martínez, santero de la Casa de Cristo y Juan Jiménez, vecino de dicha villa (Moratalla) y sucedió así: estaban ambos en una era por el mes de agosto y vieron venir del cielo un lucero muy grande que les pareció era como una rueda de molino y muy resplandeciente que pasó por encima y cerca de ellos, camino de oriente a poniente, y les calentó su resplandor: estando pues viendo dicho lucero como iba poniendo y desapareciendo, volvieron la cabeza y vieron en un hermoso resplandor a una imagen de la Virgen de Nuestra Señora distante de ellos dos pasos. Entendieron ser cosa sobrenatural y se postraron en tierra dándole rendida adoración: Hablóles la imagen Sma. y les dijo: Avisar en dicha villa lo que habían visto y que como vivían tan descuidados, que habían dejado perder su ermita que supieran que aquel lucero que había pasado era una centella que quería enviar su hijo para destruir la tierra y que no lo había hecho a ruego suyo: Que volvieran a fabricar la hermita si la querían tener por mediadora ${ }^{36}$.

35 Ibid., p. 233.

36 José Villalva y CórColes, Pensil del Ave María. Historia sagrada de las imágenes de María Santísima (1730). Manuscrito depositado en el Archivo Municipal de Murcia, signatura 1-J-1; folios 392 y ss. Es una copia hecha en el siglo XIX. 
Ambos hombres refirieron en Moratalla cuál era la voluntad de la Virgen y, tras hacer información jurídica de lo sucedido, se volvió a reedificar la ermita colocándose la imagen de la Virgen en el camarín.

Asimismo, se nos refiere en este escrito que la fiesta de la Virgen de la Rogativa vino celebrándose el día de la Ascensión, acudiendo a ella el clero y autoridades civiles y militares de Moratalla

También de innumerables gentes que concurren este día de los lugares circunvecinos. También una muy lucida compañía de mosqueteros, que hacen un ruidoso estruendo al celebrar la función. Van delante de la procesión. Dicha procesión se hace por la mañana, antes de la misa, van al humilladero, llamado así porque es donde se apareció la Santa Virgen donde hay otra hermita. Llueven en quien ha de llevar la imagen en santa y devota emulación pues todos quieren llevarla, y lo hacen los que ofrecen más en voz alta. A veces toman unos las andas, pero las tienen que dejar pues hay otros que pujan más. Así juntan los mayordomos para la Virgen en dinero y en trigo, aceite y joyas de mucho valor. Se reparten a todos pan bendito y una colación ${ }^{37}$.

Las leyendas de las apariciones de Jesucristo y de la Virgen de la Rogativa nos dicen de la sacralización del campo de la Encomienda de Moratalla, según venía haciéndose en muchos lugares españoles desde que se inició la reconquista en Cantabria, por más que ahora se formulase de manera manifiesta también sobre hombres del pueblo como pastores, labradores, santeros o ermitaños, tal como demandaban los nuevos planteamientos sociales, lo que, en este caso concreto, condujo a la apertura y conquista del espacio que se abría desde las mismas puertas de la muralla, de manera muy diferente. Todo ello, a la vez, por hacerse desde nuevos presupuestos, llevó a la consolidación de lo que se entendería por religiosidad popular, un cuerpo de creencias, sentimientos, actos, ritos, cofradías, hermandades, fiestas, que han colmado hasta hoy el alma del hombre del pueblo, al enfrentarse con el hecho de la divinidad desde la permanente sorpresa y limitada comprensión del mundo que le rodeaba y en el que desarrollaba su actividad laboral y social. Hasta entonces, como sabemos, las apariciones, desde la configuración de descubrimientos, se habían desarrollado sobre sepulcros, aparición de reliquias, etc. por personas de la nobleza u hombres de la Iglesia, en lo que hemos de ver como una colonización y repoblación. Por sólo citar un ejemplo, este es el caso de la legendaria fundación del monasterio de San Juan de la Peña (Huesca), llevada a cabo poco después de la entrada de los árabes en España por el joven caballero Voto cuando perseguía a un ciervo por el áspero y fragoso

37 Ibid., fol. 394. 
monte Pano, en las cercanías de Jaca, que le condujo hasta la boca de una cueva en la montaña, donde se internó para encontrar el cuerpo insepulto de un anacoreta que resultó ser Juan de Atares. El monasterio se consagró en el año 842 según la regla de San Benito, siendo después panteón de la nobleza de Aragón y depósito de la reliquia del Graal o santo Cáliz de la Última Cena que, según una de tantas tradiciones piadosas sobre ese vaso, había sido traído a Huesca por el diácono Lorenzo de Huesca ${ }^{38}$. Los mismos elementos aparecen en el monacato repoblador, por recordar otro ejemplo concreto, llevado a cabo durante los siglos IX, X y XI en los valles de Tobalina, Losa, Valdegovía, Mena, en las tierras occidentales de Álava, bien por monasterios pactuales o monasterios familiares, así como por anacoretas en cuevas ${ }^{39}$.

En las proximidades de Moratalla, en la Villa de Segura de la Sierra, pocos años después de que fuese reconquistada por el rey Alfonso $\mathrm{X}$, en el año 1250, fue encontrada, bajo una losa de piedra que movió la reja de un labrador, una imagen de la Virgen que se presentó con resplandores y música de ángeles. La imagen había sido enterrada para que no fuera profanada por los moros. Esta imagen, según la tradición, había sido traída de Tierra Santa en tiempos de San Eufrasio, discípulo de Santiago Apóstol, a los cuarenta y cinco años del nacimiento de Jesús, cuando vino a España para predicar el cristianismo, llegando a ser obispo de Andújar. La imagen fue llevada en procesión al pueblo, pero milagrosamente volvió al lugar donde había sido encontrada, por lo que se levantó allí un convento ${ }^{40}$. En Jaén sucedió algo semejante con la imagen de la Virgen Coronada, que también dio lugar a que se levantase una ermita y se formase posteriormente una cofradía, con carácter de milicia, con el encargo de salvaguardar en los campos a los labradores de las algaradas de los moros granadinos ${ }^{41}$.

Por otro lado, desde el siglo XIII, como en numerosos lugares de Castilla, Aragón o Cataluña, en muchos del Reino de Murcia, tanto por la Iglesia como por la Encomienda, se había procurado regular y propagar la devoción

38 Tomás Ximénez de Embứn, Crónica de San Juan de la Peña (Madrid, 1876). En Zurita, Anales, lib. I, cap. II. Sobre el monasterio como sepulcro de la nobleza de Aragón, ver R. Del Arco y GARAy, El Real Monasterio de San Juan de la Peña (Jaca, 1919).

39 Saturnino RuIz DE LoIZAGA, Monasterios altomedievales del occidente de Alava: Valdegovía (Vitoria, 1982), pp. 49 y ss. Ver J. ORLANDIS, Estudios sobre instituciones monásticas medievales (Pamplona, 1971). A. LINAJE CONDE, Los orígenes del monacato benedictino en la Península Ibérica (León, 1973), 3 vols.

40 J. Villalva y Córcoles, op. cit., fol. 417.

41 M. Soledad LÁzaro Damas, «Ermitas y santuarios de la ciudad de Jaén en el siglo XVI», La religiosidad popular (Barcelona, 1989), III, p. 288. 
a determinados santos y mártires al considerarlos como abogados y mediadores ideales contra determinadas epidemias, como la peste y la rabia, o propiciar la necesaria lluvia, para lo que les otorgaron la consideración de santos patronos protectores de las villas y ciudades, o levantaron en su honor pequeñas ermitas en las proximidades de las ciudades o intramuros, a las que se podía acudir para orar o en determinadas ocasiones.

San Sebastián, San Cosme y San Damián, San Antón, San Blas, Santa Quiteria, Santa Eulalia de Mérida, San Bartolomé, San Onofre, San Antonio de Padua, Santa Ana, San Abdón y San Senén, Santiago, San Roque, Santa María Magdalena, San Ginés, los Santos Inocentes, San Gregorio, fueron los santos que con mayor frecuencia pasaron a ser los patronos más aceptados de los lugares murcianos.

En Moratalla, por iniciativa de la Orden de Santiago, se había levantado una pequeña ermita en honor de Santa Quiteria, de la que tenemos noticias por el informe de los visitadores de 1507, que nos la describe situándola a media legua de la villa:

Es vna yglesia fecha de vna boueda de cal e canto bien fecha; tiene vn altar y en el la ymagen de señora santa Quiteria, de bulto, y en las espaldas del dicho altar esta vn lienço puesto en madera a manera de retablo e en el pintada la quinta con çiertas ymajenes pintadas. Ençima de la dicha boueda estan otros dos cuerpos de casa ${ }^{42}$.

En la visita se habla de la presencia de un ermitaño, fray Juan Frexneda, que la tenía por provisión del rey, y que por los informes que obraban «non hera onbre que biuia bien y en la quenta que se le tomo hallaron que auia vendido vna casa que la dicha hermita tenia en Hellin por treynta y çinco mil marauedies e non los tenia puestos en recibo $[\ldots]$ » ${ }^{43}$. Otra ermita que había en la Encomienda a principios del siglo XVI, un poco separada de Moratalla, era la dedicada a los santos mártires San Sebastián y San Fabián. Era un cuerpo de casa con techo a dos aguas en el que había un altar pintado con los dos bienaventurados, junto a otro de San Francisco y Santa Catalina, en uno de sus lados, mientras que en el otro

42 M. Rodríguez Llopis, op. cit., p. 191. Santa Quiteria se tuvo como ejemplo de la virtud de la castidad y como mediadora ante ciertas enfermedades como la hidrofobia. Su culto estuvo muy difundido durante la Edad Media. En Murcia, en 1400, tuvo una ermita dentro de las murallas de la ciudad, de la que salieron durante siglos las procesiones de penitencia pública. Ver Nicolás ORTEGA PAGÁn, Callejero murciano (Murcia, 1973), p. 391.

43 M. Rodrfguez Llopis, op. cit., p. 193. 
había uno de Santiago. En otro lienzo estaba representada la imagen de la Virgen.

Como podemos ver por los escuetos datos que nos es posible utilizar, a fines del siglo XV y comienzo del XVI, en Moratalla, se hallaba planteado el conflicto entre una forma de entender la religión como una regulación más de la vida social por parte de la autoridad política y eclesiástica y un afloramiento del espíritu popular, manifestándose a través de un laicado que se hacía cada vez más patente, poniendo en evidencia que también ellos podían estar presentes ante la divinidad. Desde el obispado, en un enfrentamiento abierto con las Órdenes Militares, que habían pasado a depender directamente del poder real, a través de Sínodos que se sucedieron con regularidad, poco a poco, se llegó a controlar perfectamente este movimiento, visto siempre con recelo: se dictaron normas sobre mil fórmulas diferentes que unas veces prohibieron la fundación de nuevas cofradías sin contar con la debida licencia, y otras regularon la forma en que podían venderse las propiedades de las ermitas y santuarios, o dictaron normas para encauzar la vida eremítica al tiempo que negaban el permiso de erección de nuevas ermitas. El brazo de la Inquisición, y con él el del poder político, vigilaba cualquier movimiento, religioso o no, que pudiera alzarse con cierta autonomía. La religiosidad popular continuó haciéndose sobre una manera de sentir, hermanándose el pueblo y la naturaleza en unas relaciones que a veces nos pueden parecer cargadas de ingenuidad por más que, en realidad, sean sumamente complejas. En Moratalla, por las condiciones que impuso su situación geográfica y la proximidad del reino nazarita de Granada que había condicionado su evolución, esta encrucijada de valores e intereses, de creencias y de derechos a participar en ellas, los encontramos de modo manifiesto en toda su intensidad al aproximarnos a unas realidades que hoy entendemos como si estuvieran envueltas en el encanto de lo legendario, pero que en su momento histórico formaron parte de la apoyatura sobre la que se desenvolvió la vida en toda su intensidad, en la soledad del individuo y en la del hombre en sociedad. Después, sobre los siglos y lo que en ellos ha sucedido, ha continuado haciéndose en sí misma lo que es la tradición, su tradición, hasta alcanzar nuestros días.

III

ROMERfA DE LA VIRGEN DE LA ROGATIVA

El cielo que cubría la mañana del último domingo del mes de mayo de 1990, en Caravaca, era luminoso. En compañía de mis amigos Faustino 
Fernández Conejero y Pedro Ballester Lorca, capellán del Santuario de la Santa Cruz, dejé aquella ciudad sobre las doce del mediodía para adentrarme en la carretera que llevaba a Puebla de don Fadrique, en Granada, cruzando tierras de sembradura y plantaciones de olivares y almendros. A la derecha, cerrando el horizonte, parda, compañera de viaje, se recortaba la sierra de Gavilán dominada por el pico dicho Pinar Negro.

Tras dejar atrás el pueblo de Barranda, enfilamos una carretera trazada a cordel que alcanzaba el puerto que salva el paso abierto entre los montículos de Mojantes y Serrata, y que durante siglos hizo de frontera de reinos. Al fondo, majestuosa, enigmática, dominante, quedaba la montaña de La Sagra. Doblamos a la derecha y tomamos en dirección del caserío de Cañada de la Cruz, que se levantaba en la juntura de la llanura y los primeros tirones de las laderas del imponente Cerro de Revolcadores, de la Sierra de Moratalla, bien poblado de carrascas, pinos, sabinas, enebros y en sus tierras bajas de espliego, salvia y otras plantas aromáticas, que parecía cerrar el paso. Los cortijos que saltaban diseminados tenían varios cuerpos de edificación que se acoplaban armoniosamente en estructuras irregulares y amplios corrales. Cruzamos el pueblo y pasamos al camino que pronto buscó entre los montes. El cielo comenzó a mostrarse cubierto de nubes que a veces lamían las cimas de los montes. La luz, como por capricho, cambiaba de intensidad una y otra vez. Las laderas de los montes, en la proximidad, bajo la arboleda, dejaban ver su suelo calcáreo y blancuzco. La mole de Revolcadores fue quedando a la derecha, mientras que por la izquierda corría la Sierra del Taibilla, tras la línea artificial que separaba las tierras murcianas de las de Albacete. A veces, al vencer una altura, después de andar entre curvas y curvas ascendentes, se abría el valle dejando ver terrenos escalonados cruzados en su fondo por un riachuelo junto al que espigaban algunas choperas de hoja plateada y verdosa. Faustino, que había pasado los años mozos por estos rincones, dijo nombres que recordaba de alguno de los caseríos que aparecían en el silencio y la lejanía: cortijo de Puerto Alto, de los Ayala, de Cantarrales... al tiempo que refería andanzas de días de caza y de excursiones a las cumbres desoladas en las que se descubrían, en la lejanía, cabras hispanas. El arroyo que discurría serpenteando en el hondón recibía varios nombres según el paraje que atravesaba: en su cabeza se le decía Rambla de Puerto Alto, después Rambla de Boguera hasta el remanso donde en otros tiempos movía las piedras del molino de Javanes, que a su vez servía de punto de entrada en el tramo de Rambla de Rogativa del que salía para convertirse en acequia que abocaba en el río Taibilla. El campo verdeaba con fuerza desde el mirador que dejaba ver por primera vez la estampa de la ermita en una pequeña loma junto al camino, mientras que en el otro lado, a 
media ladera de la umbría del Servalejo, blanqueaba el altar cubierto que marcaba el sitio preciso en que se apareció la Virgen en aquel lejano año de 1535. En el telón de fondo del cielo, las nubes negras, a veces deshilachadas, a veces apretadas, corrían llevadas por el viento del norte. La luz, cuando calaba, era brillante.

Al bajar del automóvill nos alcanzó el murmullo sordo de los romeros que remolineaban en torno de la ermita y las manchas de color junto a alguna voz de los que se disponían a comer bajo los árboles próximos.

A la ermita se llegaba por una rampa en que habían plantado sus tenderetes de chucherías, velas, estampas de la Virgen, helados, juguetes, etc. los feriantes que en aquellas horas de remanso permanecían atentos, aunque se mostraban con cierto despego. La ermita es un edificio con trazas propias del siglo XVI o XVII compuesto por una nave con tejado a dos aguas y espadaña rematada en veleta fija que sostiene una campana. En la puerta y lado sur corre un porche de maderos muy vencidos sobre recios soportes de mampostería en el que habían levantado su puesto los que habían madrugado para así poder ofrecer frutos secos, turrón, pan de higo, palmito, caramelos y otros comestibles, así como bebidas refrescantes y toda clase de licores propios de día de fiesta. En su interior, a la izquierda, en un cuarto mediano, ardían cientos de velas dispuestas con orden en el suelo y en soportes de hierro. En la habitación contigua, que hacía las veces de sacristía, colgadas de percheros y ganchos en los muros, se exponían las prendas y exvotos donados a la Virgen en señal de cumplimiento de la promesa hecha en horas de angustia: trenzas de cabellos, moños, vestidos de novia y de primera comunión..., cada uno con un papel prendido en que figuraban escritos el nombre y el lugar de los donantes. En el camarín, sobre el altar, decorado de alto en bajo con pinturas del siglo XVIII que refieren con ingenuidad plástica los sucesos de la aparición al pastor Ginés Valero, y pasajes de la vida del Niño Jesús, estaba la imagen de la Virgen de la Rogativa dispuesta ya sobre un pequeño trono a falta de las andas, con traje blanco, capa azul celeste, que a su vez se cubría con manto blanco, una corona plateada sobre su cabeza; en su mano izquierda, una figura del Niño Jesús, y en la derecha un cetro. En los bancos corridos de la iglesia no faltaban fieles que oraban en un murmullo silbante.

La sacristana, Concepción López González, procuraba atender a todo el que por una cosa o por otra se llegaba hasta ella para solicitarle alguna información, a la vez que confirmaba que el señor obispo de la diócesis iba a decir la misa aquella misma tarde. De cuando en cuando echaba una mirada a las velas, no sucediese como una vez que, debido al calor, algunas de ellas se vencieron y estuvieron a punto de ocasionar una desgracia. 
Pasada la hora de la comida, poco a poco, comenzó a concentrarse la gente venida a la romería y que había estado dispersa bajo los árboles cercanos, así como otros muchos que lo hacían ahora. En su mayor parte eran de Moratalla, de Caravaca, de Nerpio, de Cañada de la Cruz, de Archivel, de Campo de San Juan, de Pedro Andrés, de Inazares, de Los Odres, de Ontur, de Barranda... Del Sabinar lo habían hecho los Animeros con sus bandurrias, violín, guitarras y platillos, dispuestos a cantar durante la procesión. Aunque a la hora de la comida se movió un paso de aire que cambió la dirección de las nubes haciendo que rompiesen a llover antes de llegar a la cima de Revolcadores, lo que obligó a muchos a salir corriendo a ampararse en los vehículos y bajo los árboles, la afluencia de gente había continuado en aumento. Tras pasar por la ermita para orar ante la Virgen, todos habían ido repartiéndose en grupos: muchas familias, apiñadas en sus tres generaciones, puestos de trajes de día señalado, pasaban saludando a otras venidas a la romería, al tiempo que los jóvenes de ambos sexos de unos y otros, con timidez y recato, hacían su conocimiento en lo que podía servir de punto de partida de otras relaciones, de las que se hablaría más despacio y en otra ocasión por quien tuviera que hacerlo. Hermanos y parientes más o menos lejanos aprovechaban para saludarse y saber de lo sucedido durante el año. Apoyados en la balconada que corre ante la ermita, amigos y conocidos que hacía tiempo que no se habían visto, posiblemente también desde la última romería a la Rogativa, hablaban de sus negocios y de recuerdos que les había traído la tormenta, como aquella vez que estaban pastoreando en el Cerro del Calar Blanco y se movió una tormenta sin que diera tiempo a guarecerse, que caían los rayos y las chispas que parecía que se acababa el mundo; todos sabían lo que era sentir la caída de los rayos, y si no, bastaba ir al monte - a cualquiera de ellos- y ver los árboles partidos y calcinados que habían sido castigados. Y si caía en un árbol, ahí paraba la cosa, pero lo peor era si te salpicaba y te dejaba paralítico de un brazo o algo peor, o cuando entraba en un animal con lo que costaba hacerlo. Grupos de muchachas, con aire desenvuelto, andaban a su aire mientras los zagalones rezongaban detrás y delante de ellas con dichos y risas. Algún chiquillo se enrabietaba pidiendo que le comprasen un juguete de vistoso plástico. Cubriendo el umbral de la puerta a la ermita, Manuela Boluda Blaya cumplía su promesa de pasar la tarde pidiendo para la Virgen por haber curado a su hijo, que había sido operado por dos veces y había sanado. A ella se acercaban hombres y mujeres de todas las edades y le depositaban en la caja desde monedas hasta billetes de mil, dos mil y hasta de cinco mil pesetas. En los puestos de la porchada, los hombres bebían café de puchero y copas de anís y coñac. 
Como venía sucediendo desde siglos, en el último domingo del mes de mayo, para conmemorar la aparición de la Virgen de la Rogativa, los miembros de aquella sociedad compuesta por gentes de los pueblos del noroeste murciano y tierras aledañas de Albacete y Granada, a los que habría que añadir los que acudían desde la capital de la región y lugares más distantes a donde fueron a parar un día en busca de trabajo, estaban allí, en torno de la ermita.

De pronto corrió un revuelo por el que se vino a saber que el señor obispo estaba en la ermita y que se iba a sacar a la Virgen para colocarla en medio del anchurón donde se iba a decir la misa. De cuando en cuando caía alguna gota que hacía que se levantasen al cielo las miradas amigas de cálculos meteorológicos. Nadie decía nada en definitiva, pero todos tenían como posible que este año se mojara la imagen, lo que no era mala señal.

Después de dicha la misa, en la que predicó el señor obispo, exhortando a los presentes a tener perpetua memoria de la Virgen de la Rogativa en todos los actos de la vida, ya que en unos se tendrá consuelo y en otros ayuda, se inició la procesión, en medio de la sorpresa de algunos que hacía unos años que no habían venido y veían ahora que se había suprimido la subasta de los lugares en las andas, o de poner la corona a la Virgen. Desde tiempo inmemorial, al tiempo de hacer la procesión, se había venido haciendo la puja para ver quiénes eran los que tenían el honor aquel año de llevar sobre sus hombros a la Virgen, con lo que a la vez se recogía un dinero muy bueno que servía para hacer frente a los gastos de la fiesta y conservar con decencia y aseo la ermita durante el año. Pero aquello, sin que nadie supiera por qué, hacía unos años que se había suprimido ${ }^{44}$.

Poco a poco se fue organizando la procesión con unas cuantas mujeres abriendo paso entre la concurrencia, que iban descalzas y llevaban en sus manos hachas encendidas. Muchos se santiaguaban y retiraban de sus cabezas el sombrero. Alguna voz gritaba un viva a la Virgen de la Rogativa que era correspondido con vehemencia. Los que estaban de conversación en los puestos de bebidas se quitaban las copas de las manos y guardaban un poco de compostura. Detrás de la imagen tocaban los músicos el repertorio de salves y cantes.

Por el temor a la amenaza de lluvia, desde el primer momento, el paso que se llevó fue vivo. Al cruzar la rambla, que traía un poco de agua, pisando y saltando sobre las piedras saledizas, hubo un poco de desconcierto,

44 Esta costumbre de pujar por llevar las andas, ponerle la corona a la Virgen, quitársela en el momento de salir la imagen a la puerta, fue recuperada en la romería de 1991 , alcanzando la cifra de 25.000 pesetas que fueron empleadas en los gastos ocasionados y en pequeñas reparaciones de la ermita. 
lo que no quitó lucimiento al cortejo. Allí iba la Virgen de la Rogativa, la Virgen blanca, al frente de cientos de fieles que la seguían por el camino, que serpenteaba la ladera del Servalejo, plantada de cebada pronta a amarillear, y que de cuando en cuando obligaba a hacer parada para que se hiciesen relevos en las andas, hacia el aparecimiento, el lugar donde fijó sus pies la Virgen, sobre el que habían levantado un templete de obra con un corto tejadillo que obligaba a que se le tuviese que quitar la corona para ser introducida en él durante el tiempo en que se rezaba una salve y en el que ella bendecía los campos. Después había que volver a la ermita, donde los que tenían más prisa, trataban ya de salir del atasco de vehículos que se había formado en la carretera.

La Virgen volvió a la ermita y poco a poco los romeros fueron dispersándose por las dos salidas del camino, hacia el Campo de San Juan y Moratalla y hacia Cañada de la Cruz. Poco a poco fue desapareciendo la concurrencia, mientras los feriantes se daban prisa con movimientos mecánicos en quitar los tenderetes, y algún parroquiano rezagado reclamaba que le sirviesen la última copa. La noche llegó cuando la sacristana Concepción López González se hacía su composición de lugar para ver por dónde debía comenzar a poner las cosas en su sitio. Un día de la semana siguiente vendrían de Moratalla con una furgoneta y se llevarían la imagen de la Virgen de la Rogativa para depositarla en la parroquia, con lo que ella no estaba muy conforme; pero quien mandaba así lo tenía dispuesto por miedo a las cosas que pasan hasta en lugares como aquél. Todavía faltaba un año. 
En los campos de Moratalla, en el norte de la región de Murcia, en tierras que permanecieron deshabitadas durante los siglos bajo medievales como consecuencia de ser frontera con el reino nazarita de Granada, se produjeron varias apariciones de Jesucristo y de la Virgen en los primeros años del siglo XVI en lo que hemos de ver como una bendición sobre los campos que estaban siendo colonizados. Una de estas apariciones fue la de la Virgen de la Rogativa que llevó a que se levantase una ermita. Hoy, el último domingo del mes de mayo continúa celebrándose una romería en su honor, dentro de una serie de ritos que la caracterizan.

In the lands of Moratalla, in the north of the region of Murcia, on the ground that was uninhabited during the low medieval centuries because of being border with the nazarita kingdom of Granada. There were severals apparitions of Jesus Christ and the Virgin on the firts years of the XVI century in what we have to see how the bendition of the lands that were being colonized. One of these apparitions, was the Virgin of Rogativa which did to built an Hermitage. Today, the last sunday of the month of May keeps celebrating a pilgrimage in her honor, within a serie of rituals that characterizes it. 

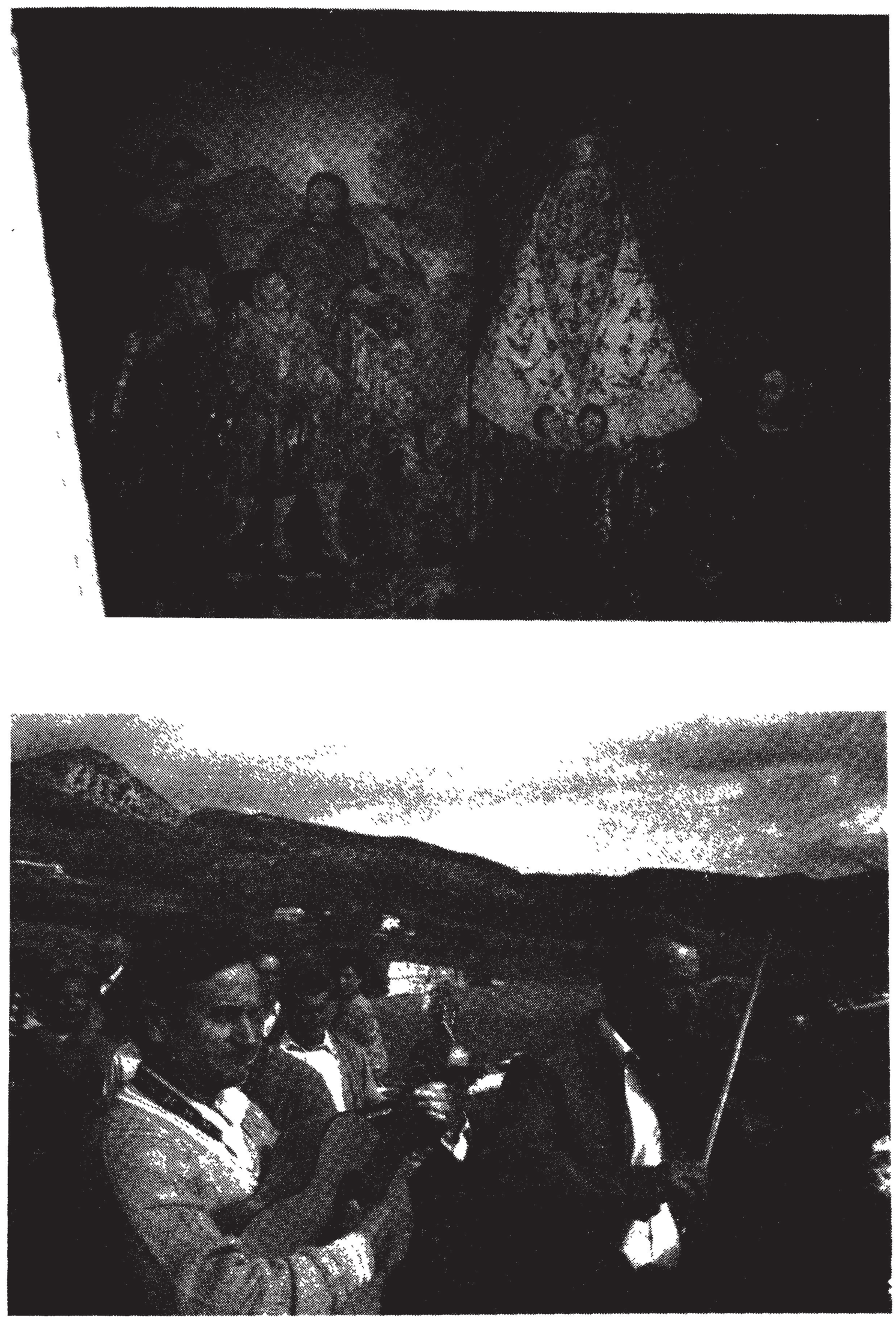

LÁmina I.-Fig. 1: Sagrada Familia en la Huida a Egipto y Aparición de la Virgen de la Rogativa. (Detalle de las pinturas del camarín. .-Fig. 2: Cuadrilla de rondadores en la procesión de la Rogativa. 

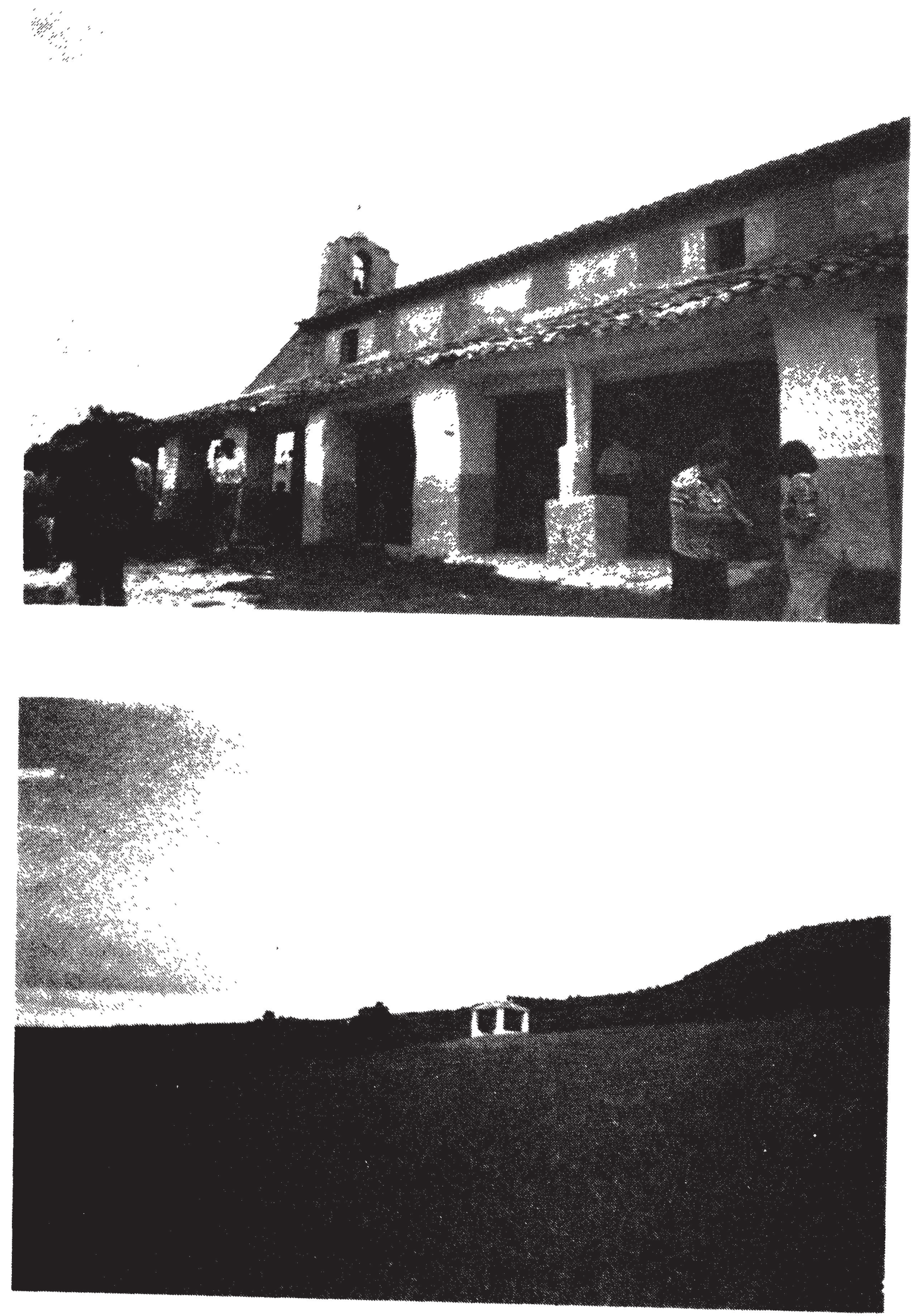

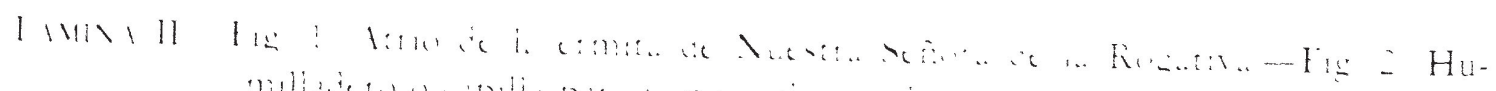

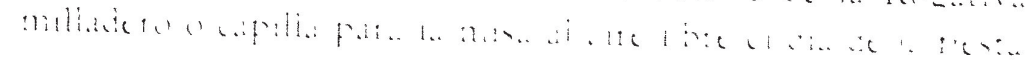



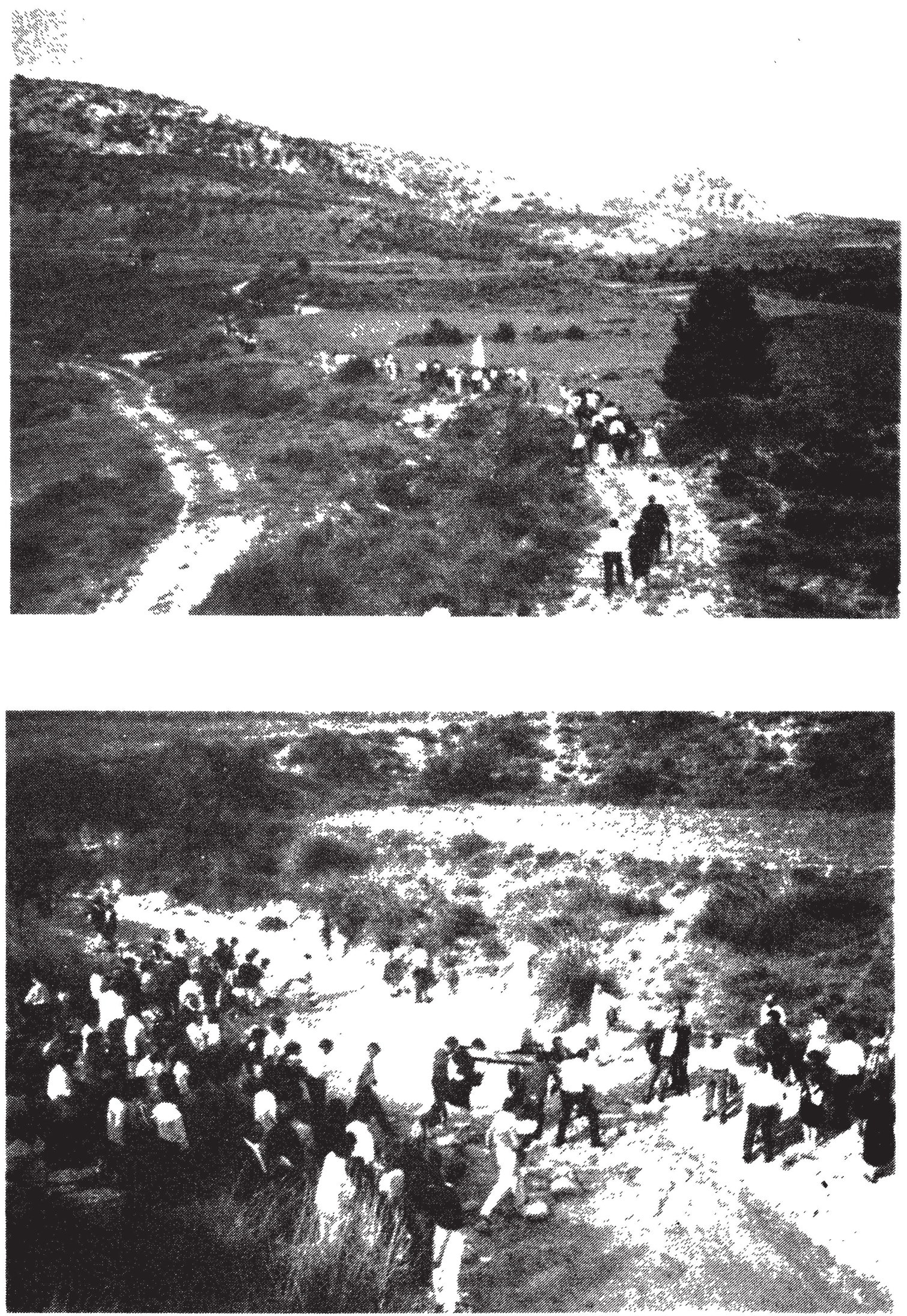

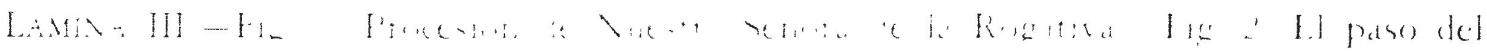



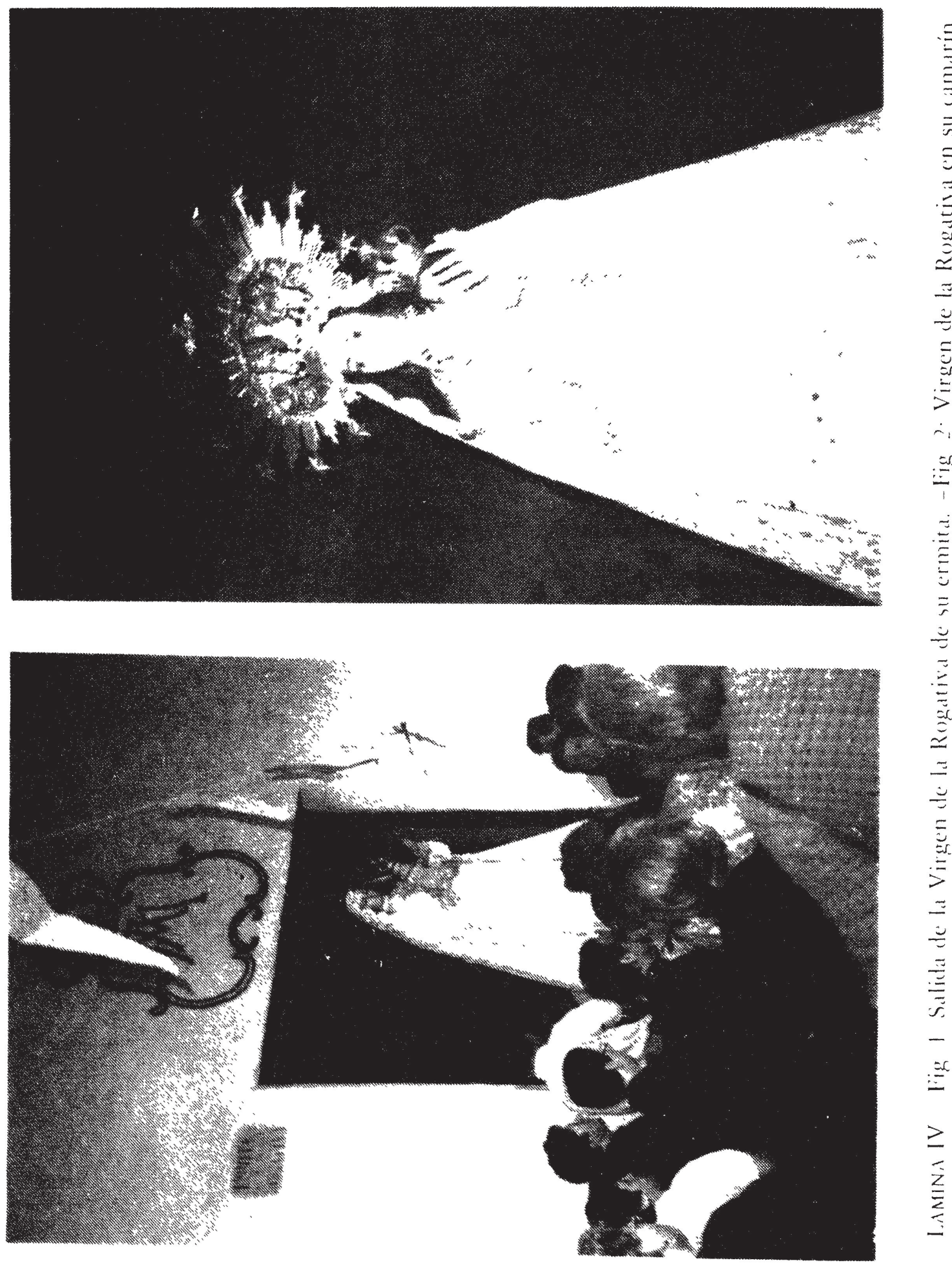